\title{
Digital Solutions and HR Marketing Opportunities: The Current Level and Prospects for Increasing Efficiency
}

Submitted 25/05/20, 1st revision 13/06/20, 2nd revision 18/07/20, accepted 30/07/20

\author{
V.A. Bondarenko ${ }^{1}$, A.A. Voronov ${ }^{2}$, P.P. Kapustin ${ }^{3}$, A.A. Maksaev ${ }^{4}$
}

\begin{abstract}
:
Purpose: The article is devoted to the prospect of the HR marketing digitalization in the context of the need to increase the efficiency of the target marketing impact in the HR solutions. Design/Methodology/Approach: The article reveals the features of the digitalization as a global trend of the corporate development, gives examples of the marketing solutions digitalization in the context of their economic efficiency, describes the possibilities of HR marketing function digitalization, and presents the results of the authors' research on the level of the spread, efficiency and digitalization of HR marketing at the regional labour market of the Southern Federal district of the Russian Federation.

Findings: The digitalization level of the HR marketing function is a promising strategic factor that determines the efficiency of target marketing efforts and the possibility of organizing the systematic marketing interaction between corporate entities and all the target audiences at the labour market.

Practical implications: Authors suggest further directions for increasing the scale of the $H R$ marketing function digitalization in terms of support for the recruitment, selection, profiling and employment procedures, evaluating the current productivity and potential of the employee, professional diagnosis and orientation procedures, planning the career and development, HR reserve and promotion to a higher position, material and non-material motivation, taking part in the corporate development and management, and outplacement interaction.

Originality/value: The authors' approach can become the basis for implementing the digital marketing management platform in the largest employer organizations of the Southern Federal district and ensure the maximum use of the modern marketing approach to manage long-term and profitable interactions with staff as key internal partners of corporate entities.
\end{abstract}

Keywords: HR marketing, regional economy, Southern Federal district, digital economy, control systems digitalization.

JEL codes: M19, M30

Paper type: Research article.

${ }^{1}$ Rostov State University of Economics, Rostov-on-Don, Russia, e-mail: b14v@yandex.ru

${ }^{2}$ Russian University of Economics named after G. V. Plekhanov (Krasnodar branch),

Krasnodar, Russia

${ }^{3}$ Kuban State University, Krasnodar, Russia

${ }^{4}$ Krasnodar Institute of Cooperation, Krasnodar, Russia 


\section{Introduction}

The digital transformation of economic relations is one of the most well-known and widely discussed concepts today, the use of which, according to the authors' conception, axiomatically leads to increase the efficiency at all levels of socioeconomic systems from households to state management structures of the economy in the regions and in the country as a whole. The experience of the digital techniques' implementation in various types of economic activity, in obtaining public services, education and science clearly indicates the prospects of digital forms that can provide substantial cost saving in all types of resources, first of all time-based ones, in the implementation of individual iterations and socio-economic processes as a whole.

At the same time, it should be noted that the use of implementing digital capabilities as part of individual corporate management functions is currently not unambiguous, and it requires a significant focus on corporate features and opportunities for increasing the economic efficiency of enterprises and organizations aimed at the massive introduction of digital approaches and techniques (Drewniak and Posadzińska, 2020).

\section{Marketing Digitalization: Solutions and Results}

Modern marketing as the corporate management function is developing in two main directions today, which perfectly should be linked by the single evaluation of the target impacts economic efficiency. These are:

- the use of traditional marketing tools and inventory focused on the designation of marketing efforts as part of the economic entity's corporate strategy;

- the use of innovative opportunities of the socio-economic and technological development at present stage aimed at the search and implementation of specific marketing potential to increase the scope and efficiency of economic entities.

It should be noted that the current level of the scientific substantiation and efficiency evaluation even of traditional marketing opportunities and impacts in the modern economy is analysed in different ways by the specialists in areas and metrics that can provide reliable marketing positioning and the development of subsequent efforts aimed at the clear and concrete result.

As an example of the applied digital techniques implementation in the basic information function of the modern trade organizations' marketing management we can use the approach by Beklova (2019) proposing an integrated digital solution for the internal marketing information system of the modern commercial enterprise. At the same time, the author's field study of the spread and functionality of the collecting internal marketing information systems in the modern shopping centres of Krasnodar region makes it possible to evaluate the existing digital opportunities for recording and researching customer flows as fragmentary ones, not related directly to the 
marketing strategy of trade organizations and their ability to attract and retain partners and consumers.

Vakhrusheva and Shalimova (2016) in their study on organizing marketing activity in catering enterprises note the need to identify and evaluate the consumer potential of customer flows in some marketing locations as the basis for the sustainable implementation of catering services related to cooking on the spot. The authors' field study of the client flows features in the target marketing location was based on the use of analogue methods of marketing research, in particular observation, due to the lack of digital capabilities for monitoring and recording the necessary flow data (Table 1).

Table 1. Client flows features obtained by analogue methods of the marketing research (Vakhrusheva and Shalimova, 2016)

\begin{tabular}{|c|c|c|c|c|c|}
\hline $\begin{array}{l}\text { The } \\
\text { consumer } \\
\text { flow }\end{array}$ & $\begin{array}{l}\text { Time } \\
\text { within the } \\
\text { location }\end{array}$ & $\begin{array}{c}\text { The } \\
\text { flow } \\
\text { size, } \\
\text { people, } \\
\text { per an } \\
\text { hour }\end{array}$ & $\begin{array}{l}\text { The } \\
\text { average } \\
\text { receipt } \\
\text { size in } \\
\text { the } \\
\text { stream, } \\
\text { RUB. }\end{array}$ & $\begin{array}{c}\text { The } \\
\text { conversion } \\
\text { of the flow } \\
\text { relating to } \\
\text { catering } \\
\text { services, } \\
\%\end{array}$ & $\begin{array}{l}\text { Key problems of } \\
\text { attracting flow } \\
\text { participants }\end{array}$ \\
\hline 1 & 2 & 3 & 4 & 5 & 6 \\
\hline Seeing off & $\begin{array}{c}15-120 \\
\text { minutes }\end{array}$ & $\begin{array}{l}100- \\
200\end{array}$ & $50-100$ & $1-5$ & \multirow{4}{*}{$\begin{array}{l}\text { In most cases, impulse } \\
\text { purchases based on the } \\
\text { actual time spent in the } \\
\text { location, the high } \\
\text { rationality of consumer } \\
\text { behaviour and } \\
\text { comparison with the } \\
\text { facilitated transit } \\
\text { documents of catering } \\
\text { enterprises outside the } \\
\text { location, the consumer } \\
\text { manoeuvre possibility } \\
\text { (moving the customer } \\
\text { between marketing } \\
\text { locations) }\end{array}$} \\
\hline Greeters & $\begin{array}{c}15-120 \\
\text { minutes }\end{array}$ & $\begin{array}{l}200- \\
300\end{array}$ & $50-200$ & $1-5$ & \\
\hline $\begin{array}{l}\text { Arriving air } \\
\text { passengers }\end{array}$ & $\begin{array}{l}15-120 \\
\text { minutes }\end{array}$ & $\begin{array}{l}300- \\
500\end{array}$ & $50-100$ & $1-5$ & \\
\hline $\begin{array}{l}\text { Service staff } \\
-\quad \text { partners } \\
\text { (not regular } \\
\text { employees of } \\
\text { the airport } \\
\text { and airlines) }\end{array}$ & $\begin{array}{l}15 \\
\text { minutes - } \\
8 \text { hours }\end{array}$ & $50-100$ & $50-100$ & $1-5$ & \\
\hline $\begin{array}{l}\text { Departing air } \\
\text { passengers }\end{array}$ & $\begin{array}{l}15-120 \\
\text { minutes } \\
\text { (up to } 480 \\
\text { minutes if } \\
\text { the } \\
\text { schedule } \\
\text { is } \\
\text { disrupted) }\end{array}$ & $\begin{array}{l}\text { Up to } \\
1400\end{array}$ & $\begin{array}{l}300- \\
1000\end{array}$ & $10-20$ & $\begin{array}{l}\text { Purchases of a mixed } \\
\text { rational-impulse type } \\
\text { related to the flight } \\
\text { distance, number of } \\
\text { transfers, interregional / } \\
\text { international distance, } \\
\text { children. There is no } \\
\text { comparison with the } \\
\text { facilitated transit } \\
\text { documents of catering } \\
\text { enterprises outside the }\end{array}$ \\
\hline
\end{tabular}




\begin{tabular}{|l|l|l|l|l|l|}
\hline & & & & & $\begin{array}{l}\text { location, the demand is } \\
\text { concentrated in the } \\
\text { waiting and departure } \\
\text { areas of domestic and } \\
\text { international airlines } \\
\text { terminals }\end{array}$ \\
\hline $\begin{array}{l}\text { VIP } \\
\text { passengers }\end{array}$ & $\begin{array}{l}15-120 \\
\text { min. }\end{array}$ & $1-5$ & $\begin{array}{c}12000 \\
\text { (package } \\
\text { proposal) }\end{array}$ & $80-100$ & $\begin{array}{l}\text { Practically there no } \\
\text { problem of attracting } \\
\text { customers since the } \\
\text { catering service is } \\
\text { provided in package } \\
\text { proposal of services paid } \\
\text { for by corporate or public } \\
\text { entities presented by the } \\
\text { air passenger }\end{array}$ \\
\hline $\begin{array}{l}\text { Airport and } \\
\text { airline staff }\end{array}$ & $\begin{array}{l}4-12 \\
\text { hours }\end{array}$ & $\begin{array}{l}1500- \\
2000 \\
\text { per a } \\
\text { day }\end{array}$ & $200-500$ & $50-75$ & $\begin{array}{l}\text { The flow is clearly } \\
\text { separated into subjects } \\
\text { that receive the services } \\
\text { of airport's catering } \\
\text { system and subjects that } \\
\text { eat independently outside } \\
\text { of this system }\end{array}$ \\
\hline
\end{tabular}

Source: Authors.

It must be admitted that the implementation and use of the digital marketing information system in the location could facilitate continuous (but not selective one) marketing surveillance, and as a result a larger array of marketing data necessary for forecasting marketing activity to optimize the participants and the catering sector of the selected location as a whole. Moreover, the successful use of the marketing observations principle in the video surveillance system for the client flow of airports (which is confirmed, for example, by the activity of the international airport "Domodedovo") makes it possible to achieve a comprehensive operational effect from complete digital support of the passenger transport services to the identification and neutralization of criminals declared on the Federal wanted list (Golovanov, 2019).

The independent direction of investigating and implementing digital marketing opportunities is the functionality of the holistic marketing paradigm, focused on the search, establishment and monetization of long-term, stable and mutually beneficial relationships with all the subjects of corporate marketing systems. We will continue our research on HR marketing - a modern marketing and management tools - an important instrument in the formation and use of competitive advantages of corporate structures.

\section{HR Marketing: Modern Approaches and Opportunities for Digitalization}


The experience of recent years in the target marketing impact implementation has indicated that "the effective use of low-budget marketing innovations aimed at a qualitatively new level of the release of employees' working capacity within the full professional life cycle makes it possible to mobilize internal reserves for the intensive increase of labour productivity, replacing the traditional full employment with a multi-format model of the competence development and partner marketing interaction" (Demyanenko, 2019).

The issue of HR marketing is connected with necessary HR training (Voronov et al., 2018; Shevchenko, 2013). In detail marketing opportunities for the HR management function implementation are investigated by Lobanova (2014) in relation to the marketing interaction subjects of a typical enterprise - employer (Table 2).

Table 2. Opportunities for the HR marketing function implementing in the modern enterprise activity (Lobanova, 2014)

\begin{tabular}{|c|c|c|}
\hline $\begin{array}{l}\text { The marketing } \\
\text { impact subject }\end{array}$ & The marketing impact direction & Marketing impact tools \\
\hline $\begin{array}{l}\text { HR of the } \\
\text { enterprises - } \\
\text { competitors }\end{array}$ & $\begin{array}{l}\text { The competition and poaching of the best } \\
\text { employees }\end{array}$ & $\begin{array}{l}\text { The employer's brand. } \\
\text { The direct recruitment. } \\
\text { Competitive forms and the } \\
\text { employment terms. }\end{array}$ \\
\hline $\begin{array}{l}\text { Job seekers } \\
\text { (persons with the } \\
\text { ability to work) }\end{array}$ & $\begin{array}{l}\text { Creating the job offer attractiveness by a } \\
\text { certain employer. Economically } \\
\text { substantiated reducing the applicants' } \\
\text { candidate expectations in wages and } \\
\text { working conditions (both during the trial } \\
\text { period and during the main work) }\end{array}$ & $\begin{array}{l}\text { The use of competitive forms of } \\
\text { the selection and recruitment of } \\
\text { the best candidates from the } \\
\text { candidates at the labour market }\end{array}$ \\
\hline $\begin{array}{l}\text { Current } \\
\text { employees of the } \\
\text { company } \\
\text { - young } \\
\text { specialists }\end{array}$ & $\begin{array}{l}\text { Professional orientation within the } \\
\text { adaptation to new work, additional } \\
\text { professional training, reaching the average } \\
\text { level of labour productivity, career planning }\end{array}$ & \multirow{4}{*}{$\begin{array}{l}\text { The employer's brand, working } \\
\text { conditions, the company's HR } \\
\text { marketing research, } \\
\text { professional orientation, } \\
\text { engagement and loyalty } \\
\text { programs, outplacement, } \\
\text { optimization of employment } \\
\text { forms, choice of the form of } \\
\text { participation in the enterprise } \\
\text { management }\end{array}$} \\
\hline $\begin{array}{l}\text { - specialists with } \\
\text { experience }\end{array}$ & $\begin{array}{l}\text { Marketing programs of engagement and } \\
\text { loyalty, the career plan implementation }\end{array}$ & \\
\hline $\begin{array}{l}\text { - specialists - } \\
\text { "veterans" }\end{array}$ & $\begin{array}{l}\text { Marketing programs of the engagement and } \\
\text { loyalty, implementation of a career plan, the } \\
\text { optimization of labour activity and forms of } \\
\text { employment, outplacement events }\end{array}$ & \\
\hline $\begin{array}{l}\text { - specialists - } \\
\text { "human capital" }\end{array}$ & $\begin{array}{l}\text { Marketing programs of the engagement and } \\
\text { loyalty, the career plan implementation, } \\
\text { optimization of labour activity and forms of } \\
\text { employment, outplacement events, choice of } \\
\text { the participation form in the enterprise } \\
\text { management }\end{array}$ & \\
\hline $\begin{array}{l}\text { Trade unions and } \\
\text { employers' } \\
\text { associations }\end{array}$ & $\begin{array}{l}\text { Cooperation in the development and } \\
\text { implementation of HR marketing standards. } \\
\text { Target employment programs }\end{array}$ & $\begin{array}{l}\text { Marketing research, standards } \\
\text { of HR marketing activity } \\
\text { engineering, communication } \\
\text { activity within the HR } \\
\text { marketing }\end{array}$ \\
\hline
\end{tabular}




\begin{tabular}{|l|l|l|}
\hline $\begin{array}{l}\text { The labour market } \\
\text { infrastructure }\end{array}$ & $\begin{array}{l}\text { Cooperation in the marketing research at the } \\
\text { different labour market, its segmentation, } \\
\text { the evaluation of functioning and } \\
\text { competition }\end{array}$ & $\begin{array}{l}\text { Marketing research of the } \\
\text { labour market, its capacity } \\
\text { structure, dynamics, factors, } \\
\text { trends, mechanisms (including } \\
\text { competition) }\end{array}$ \\
\hline $\begin{array}{l}\text { Educational } \\
\text { institutions: } \\
\text { secondary } \\
\text { vocational } \\
\text { educational and } \\
\text { high educational } \\
\text { establishments }\end{array}$ & $\begin{array}{l}\text { Correction of educational programs aimed at } \\
\text { creating the competitive professional } \\
\text { competence of young specialists. }\end{array}$ & $\begin{array}{l}\text { Oarketing research of the } \\
\text { educational services and products. } \\
\text { Interaction with employers and job seekers } \\
\text { on continuing professional education. } \\
\text { Engineering of educational } \\
\text { services and products under the } \\
\text { programs of secondary } \\
\text { vocational education, higher } \\
\text { education and postgraduate } \\
\text { seekers at the labour market during the } \\
\text { training stage and forming marketing } \\
\text { relationships) } \\
\text { Marketing support of } \\
\text { prospective students for the } \\
\text { period of graduating from the } \\
\text { educational establishments. }\end{array}$ \\
\hline $\begin{array}{l}\text { The state and its } \\
\text { representative } \\
\text { structures }\end{array}$ & $\begin{array}{l}\text { Providing marketing information about } \\
\text { labour market activity. } \\
\text { Target employment programs for certain } \\
\text { categories of the population. } \\
\text { Compliance with standards and rules of } \\
\text { social and labour relations and prevention of } \\
\text { their manipulation. }\end{array}$ & $\begin{array}{l}\text { Marketing research on the } \\
\text { labour market. } \\
\text { Communication activity within } \\
\text { HR marketing. }\end{array}$ \\
\hline
\end{tabular}

Source: Authors.

At the same time, according to research results on the spread and efficiency of the HR marketing use, presented by Demyanchenko (2019) on the material of the 50 largest Russian employers in 2018 , only $22 \%$ of respondents noted the declaration of HR marketing functions in the HR policy of the enterprise. Only $4 \%$ of respondents noted the long-term HR marketing plan, and $10 \%$ of respondents noted the short-term plan. Only $4 \%$ of respondents noted the time-based structure of HR marketing, although the permanent structure of HR marketing (in the form of at least a corporate training structure) was available in $44 \%$ of organizations under consideration. In $68 \%$ of organizations, the fact of evaluating the HR marketing function implementation was just announced, but not evaluated. Only $8 \%$ of respondents noted that specialized quantitative indicators were used in their organisations $(24 \%$ of responses were qualitative/expert ones). As the main indicators used for the efficiency of the HR marketing function implementation in the organization, indicators of labour productivity in general in the short term was identified by $28 \%$ of respondents the staff turnover during the short period was identified by $28 \%$ of respondents, the socioeconomic climate of the staff was identified by $32 \%$ of respondents, and other marketing effects were considered and used to a much lesser extent.

These conclusions are not opposite to the conclusions presented in other studies (Vanyan and Demyanenko, 2016; Mitrofanova et al., 2017; Vladyka et al., 2016; Yeremeyev and Kublin, 2011). 


\section{The Field Research: The Level of Spread, Efficiency and Digitalization of HR Marketing at the Regional Labour Market}

In order to evaluate the current level of the HR management function digitalization and its marketing tools, we made the express research on the material of the 250 largest employers-organizations of the Southern Federal district. This express research was presented in the rating of the Research Agency "Expert-South" (Expert, 2019). The research plan and methodology are presented in Table 3.

Table 3. The plan and methods for the express research on the HR management function digitalization level and its marketing tools in the largest corporate entities of the Southern Federal district (the author's research)

\begin{tabular}{|c|c|}
\hline Stage & Contents \\
\hline 1 & 2 \\
\hline & The research conception development \\
\hline $\begin{array}{l}\text { 1.1. Identifyi } \\
\text { ng the problem }\end{array}$ & $\begin{array}{l}\text { The HR marketing function implementation efficiency level and its digital tools } \\
\text { significantly constrains the growth of the strategic function of HR management } \\
\text { in the Russian enterprises at present and requires the activation of search and } \\
\text { rationalization efforts to apply digital marketing capabilities in the key } \\
\text { problems such as the formation, use and development of HR in the largest } \\
\text { corporate entities of the Southern Federal district. }\end{array}$ \\
\hline $\begin{array}{l}1.2 . \\
\text { goals }\end{array}$ & $\begin{array}{l}\text { 1. The HR marketing function spread in HR management is the research object. } \\
2 \text {. The evaluation of the management marketing function digitalization level } \\
\text { and promising directions for its improvement in the context of increasing the } \\
\text { efficiency and competitiveness of corporate structures. }\end{array}$ \\
\hline $\begin{array}{l}\text { 1.3. Formulat } \\
\text { ing the working } \\
\text { hypothesis of the } \\
\text { study }\end{array}$ & $\begin{array}{l}\text { The HR marketing function digitalization level is the fac } \\
\text { efficiency of target marketing efforts and possibility to o } \\
\text { marketing interaction between corporate entities and all } \\
\text { the labour market. }\end{array}$ \\
\hline \multicolumn{2}{|c|}{ The selection of information sources } \\
\hline $\begin{array}{l}\text { 2.1. Secondary } \\
\text { information }\end{array}$ & $\begin{array}{l}\text { Data from the Expert South News Agency on the largest c } \\
\text { the Southern Federal district in 2018-2019. }\end{array}$ \\
\hline $\begin{array}{l}\text { 2.2. Primary } \\
\text { information }\end{array}$ & $\begin{array}{l}\text { Data from the Express survey of representatives of HR departments of the } \\
\text { largest economic enterprises in the Southern Federal district of the Russian } \\
\text { Federation. }\end{array}$ \\
\hline \multicolumn{2}{|c|}{ 3. $\quad$ Data collecting } \\
\hline & $\begin{array}{l}\text { Data is collected in accordance with the research goals. Secondary information } \\
\text { is obtained from the ranking data of the research agency "Expert South". } \\
\text { Empirical data is obtained from the survey of HR representatives in the } 250 \\
\text { largest corporate structures of the Southern Russia's economy }\end{array}$ \\
\hline \multicolumn{2}{|c|}{ The field stage } \\
\hline & dy is September-October of 2019 \\
\hline \multicolumn{2}{|c|}{ The information analysis, making conclusions and recommendations } \\
\hline & $\begin{array}{l}\text { The research results are intended to characterize the current level of using } \\
\text { approaches and techniques of HR marketing in the activity of the largest } \\
\text { companies - employers, to evaluate the marketing sub-function digitalization } \\
\text { level and the prospects for increasing its spread and efficiency. }\end{array}$ \\
\hline
\end{tabular}

Source: Authors.

The key results obtained during the study are presented in Table 4. 
Table 4. Key results of the express study of the HR management function digitalization level and its marketing tools in the largest corporate entities of the Southern Federal district (author's study)

\begin{tabular}{|c|c|c|}
\hline Question/ responses options & $\begin{array}{l}\text { Number of } \\
\text { responses }\end{array}$ & $\begin{array}{l}\text { Response } \\
\text { rate }\end{array}$ \\
\hline 1 & 2 & 3 \\
\hline \multicolumn{3}{|l|}{$\begin{array}{l}\text { 1. The availability of the HR marketing function in the HR } \\
\text { management system at the enterprise }\end{array}$} \\
\hline available in full format & 24 & 9,6 \\
\hline available in the form of fragmented efforts & 114 & 45,6 \\
\hline not available & 112 & 44,8 \\
\hline \multicolumn{3}{|l|}{$\begin{array}{l}\text { 2. The quantitative evaluation of the HR marketing function based on } \\
\text { the results of the reporting period }\end{array}$} \\
\hline evaluated & 24 & 9,6 \\
\hline evaluated: positive dynamics & 16 & 66,67 \\
\hline evaluated: neutral dynamics & 6 & 25,00 \\
\hline evaluated: decreasing dynamics & 2 & 8,33 \\
\hline not evaluated & 226 & 90,4 \\
\hline \multicolumn{3}{|l|}{$\begin{array}{l}\text { 3. The expert evaluation of the HR marketing function } \\
\text { implementation in the enterprise }\end{array}$} \\
\hline It contributes to the growth of operating performance indicators & 87 & 34,8 \\
\hline It promotes the labour productivity growth & 92 & 36,8 \\
\hline It helps reduce HR management costs & 85 & 34 \\
\hline \multicolumn{3}{|l|}{$\begin{array}{l}\text { 4. The HR marketing function digitalization level in the enterprise as } \\
\text { a whole }\end{array}$} \\
\hline the HR marketing function is fully digitalized & 14 & 10,1 \\
\hline the HR marketing function is partially digitized & 98 & 71,0 \\
\hline the HR marketing function is not digitalized & 26 & 18,8 \\
\hline \multicolumn{3}{|l|}{$\begin{array}{l}\text { 5. The main directions of HR marketing functions implemented in the } \\
\text { corporate HR model }\end{array}$} \\
\hline $\begin{array}{l}\text { support for the recruitment, selection, profiling and employment } \\
\text { procedures }\end{array}$ & 94 & 68,1 \\
\hline $\begin{array}{l}\text { support for procedures of evaluating the current employee's efficiency and } \\
\text { potential }\end{array}$ & 23 & 16,7 \\
\hline $\begin{array}{l}\text { support for the professional diagnostics and orientation, career planning } \\
\text { and development }\end{array}$ & 19 & 13,8 \\
\hline support for HR reserve and promotion procedures & 87 & 63,0 \\
\hline support for material and non-material motivation procedures & 111 & 80,4 \\
\hline support for participation in the corporate development and management & 15 & 10,9 \\
\hline support for the outplacement interaction procedures & 3 & 2,2 \\
\hline others & 101 & 73,2 \\
\hline \multicolumn{3}{|l|}{$\begin{array}{l}\text { 6. The digitalization level of the main directions of the HR marketing } \\
\text { function implemented in the corporate HR model }\end{array}$} \\
\hline $\begin{array}{l}\text { support for the recruitment, selection, profiling and employment } \\
\text { procedures }\end{array}$ & 94 & 68,1 \\
\hline sufficient & 28 & 29,79 \\
\hline insufficient & 66 & 70,21 \\
\hline $\begin{array}{l}\text { support for procedures to evaluate the current employee's efficiency } \\
\text { and potential }\end{array}$ & 23 & 16,7 \\
\hline sufficient & 4 & 17,39 \\
\hline insufficient & 19 & 82,61 \\
\hline
\end{tabular}




\begin{tabular}{|c|c|c|}
\hline $\begin{array}{l}\text { support for the professional diagnostics and orientation, career } \\
\text { planning and development }\end{array}$ & 19 & 13,8 \\
\hline sufficient & 2 & 10,53 \\
\hline insufficient & 17 & 89,47 \\
\hline support for the personnel reserve and promotion procedures & 87 & 63,0 \\
\hline sufficient & 17 & 19,54 \\
\hline insufficient & 70 & 80,46 \\
\hline support for the material and non-material motivation procedures & 111 & 80,4 \\
\hline sufficient & 34 & 30,63 \\
\hline insufficient & 77 & 69,37 \\
\hline $\begin{array}{l}\text { support for participation in the corporate development and } \\
\text { management }\end{array}$ & 15 & 10,9 \\
\hline sufficient & 2 & 13,33 \\
\hline insufficient & 13 & 86,67 \\
\hline support for the outplacement interaction procedures & 3 & 2,2 \\
\hline sufficient & 0 & 0,00 \\
\hline insufficient & 3 & 100,00 \\
\hline \multicolumn{3}{|l|}{$\begin{array}{l}\text { 7. The HR marketing function impact on the main efficiency } \\
\text { indicators of the enterprise }\end{array}$} \\
\hline \multicolumn{3}{|l|}{ The labour productivity } \\
\hline positive & 67 & 48,55 \\
\hline neutral & 54 & 39,13 \\
\hline decreasing & 17 & 12,32 \\
\hline \multicolumn{3}{|l|}{ The unproductive staff turnover } \\
\hline positive & 56 & 40,58 \\
\hline neutral & 76 & 55,07 \\
\hline decreasing & 6 & 4,35 \\
\hline \multicolumn{3}{|l|}{ reducing the cost of HR management implementation } \\
\hline positive & 44 & 31,88 \\
\hline neutral & 79 & 57,25 \\
\hline decreasing & 15 & 10,87 \\
\hline \multicolumn{3}{|l|}{ etc. } \\
\hline positive & 89 & 64,49 \\
\hline neutral & 43 & 31,16 \\
\hline decreasing & 6 & 4,35 \\
\hline \multicolumn{3}{|l|}{$\begin{array}{l}\text { 8. The availability of the independent budget of HR marketing } \\
\text { functions in the enterprise }\end{array}$} \\
\hline available & 34 & 13,6 \\
\hline not available & 216 & 86,4 \\
\hline \multicolumn{3}{|l|}{$\begin{array}{l}\text { 9. The size of the independent budget of HR marketing functions in } \\
\text { the enterprise }\end{array}$} \\
\hline up to 1 million rub. per a year & 22 & 91,67 \\
\hline 1-10 million rub. per a year & 2 & 8,33 \\
\hline more than 10 million rub. per a year & 0 & 0,00 \\
\hline \multicolumn{3}{|l|}{$\begin{array}{l}\text { 10. Prospects for increasing the HR marketing budget at the } \\
\text { enterprise }\end{array}$} \\
\hline planned & 2 & 8,33 \\
\hline unplanned & 22 & 91,67 \\
\hline
\end{tabular}

Source: Authors. 
9.6\% of respondents noted the availability of the full-format HR marketing function in their enterprises. $45.6 \%$ of respondents note fragmentary attempts to use marketing methods and tools in the corporate HR management system. Only $9.6 \%$ of respondents carried out the quantitative evaluation of the HR marketing function implementation efficiency, while $66.67 \%$ of them considered it successful. In general, respondents assumed the positive impact of HR marketing tools on operating results, labour productivity, and reducing costs for HR management, although the corresponding reports were not made at the enterprises they represented.

Only $10.1 \%$ of respondents stated that the personnel marketing function was fully digitalized, $71 \%$ of responses noted partial attempts to use digital tools and software, and $18.8 \%$ of respondents noted the analogue format of the HR marketing function. $13.6 \%$ of respondents stated about the independent budget for HR marketing but in $91.67 \%$ of cases it did not exceed 1 million rub. per year and the prospects for its increase were evaluated negatively.

\section{Conclusion on the Prospects and Forecasts of Increasing the Efficiency of HR-Digital Solutions}

The research indicated the initial level of the HR marketing function implementation and its digitalization in the largest corporate entities of the economy in the Southern Federal district. Status quo is due to the lack of the economic efficiency substantiation of HR marketing decisions, significant and not obvious in terms of payback for its digitalization, and some scepticism of managers who in unstable economic situations prefer to save on investment in the future corporate development. At the same time, a lot of enterprises are interested in HR marketing and increasing its application, and its specific approaches, models and tools require the further development and testing in the HR management systems of modern Russian enterprises.

\section{References:}

Demyanchenko, N.V. 2019. The development of the holistic paradigm of HR marketing in the corporate strategy of the organization. Abstract of unpublished theses of $\mathrm{PhD}$ in Economics, Rostov-on-Don, RSUE publishing.

Drewniak, Z., Posadzińska, I. 2020. Learning and Development Tools and the Innovative Potential of Artificial Intelligence Companies. European Research Studies Journal, 23(2), 388-404. DOI: 10.35808/ersj/1599.

Expert. 2019. Big business of the Southern Federal district: acceleration of 2018. 2019. Available at: https://expert.ru/south/2019/09/krupnyij-biznes-yufo-uskorenie-2018goda/.

Golovanov, G. 2019. In Domodedovo, the facial recognition system has started working. Available at: https://hightech.plus/2019/07/05/v-domodedovo-zarabotala-sistemaraspoznavaniya-lic.

Lobanova, V.V. 2014. HR Marketing as an element of corporate strategy of a modern enterprise. Abstract of unpublished theses of PhD in Economics. Krasnodar, Kuban State University. 
Mitrofanova, S.V., Demyanchenko, N.V., Novikov, S.V., Rudakova, O.V., Shmanev, S.V. 2017. The role and characteristics of the enterprises' working conditions before and after the transition to market relations: a view from macroeconomic perspective. International Journal of Applied Business and Economic Research, 13(15), 63-72.

Shevchenko, D.A. 2013. The Position of the market of higher professional education in Russia and prospects for its development. Marketing in Russia and abroad, 3, 109 121.

Vakhrusheva, N.V., Shalimova, V.Yu. 2016. The flow organization of marketing interaction as the basis for the stability of operating activity of modern catering enterprises. Economics of the sustainable development, 4, 96-104.

Vanyan, M.N., Demyanenko, N.V. 2016. The HR involvement as an effect of marketing activity relating to the enterprise employees. Economics of the sustainable development, 1(25), 71-79.

Vedomosti. 2019. Result of the face detection framework. Available at: https://www.vedomosti.ru/technology/articles/2019/06/26/805163-mvd-podvelo.

Veklova, E.V. 2019. Integrated marketing information systems of modern shopping centres. Abstract of unpublished theses of PhD in Economics, Rostov-on-Don, RSUE.

Vladyka, M.V., Vaganova, O.V., Kucheryavenko, S.A., Bykanova, N.I. 2016. Analysis of efficiency indicators of a macro region's economy (on the example of the Central Federal district). The Social Sciences (Pakistan), 15(11), 3728-3733.

Voronov, A.A., Garkovenko, V.E., Safonov, A.M., Kosnikov, S.N. 2018. Higher education competitiveness: Definition, assessment, and ways of growth. European Research Studies Journal, S1(21), 525-534.

Yeremeyev, M.A., Kublin, I.M. 2011. Formation of principles for ensuring the efficiency of the remuneration and labour incentive system. Modern economy: problems and solutions, 1(13), 83-92. 